\title{
アマチュア無線機材を用いた超小型衛星の軌道要素補正手法の研究"1 A Correction Method of Orbit Elements Using Amateur Radio Facilities for Nano-Satellites
}

\author{
小田靖 久 $^{* 2} \cdot$ 中須賀 真 ${ }^{* 3} \cdot$ Priya FERNANDO $^{* 4}$ \\ Yasuhisa ODA ${ }^{* 2}$, Shinichi NAKASUKA ${ }^{* 3}$ and Priya FERNANDO ${ }^{* 4}$ \\ Key Words: Orbit Element, Amateur Radio, Cubesat, Ground Station
}

\begin{abstract}
A correction method of orbit elements for nano-satellites using simple and low cost facilities is required. In this study, the Doppler shift of the beacon signal from a cubesat was observed using an amateur radio. The history of frequency variation was recorded for different TLEs with different epoch time. The frequency difference translated into seconds (FDTS) was deduced as a ratio of the maximum frequency variation in the pass to the 1s-periodic variation. The FDTS has dependency on TLE. For the old TLE, the FDTS was larger than the new one. Because the FDTS is related to satellite's phase variation in the orbit, the TLE's epoch time was corrected using the measurement result. The FDTS with the observation using the corrected TLE was small.
\end{abstract}

\section{1. はじめに}

近年, 超小型衛星が世界各国で開発・運用されているが, この数年の間に, 超小型衛星開発を取り巻く環境は大きく 変化しつつある. 中でも, 超小型衛星の打ち上げ機会の確 保や, 周波数調整, 運用ネットワークといった, 衛星開発 運用を支えるインフラ環境が整えられている。その中にあ って，衛星の軌道決定に関しては，様々な衛星プロジェク トに軌道情報を提供してきた NORAD により，1 kg 級人工 衛星に至るまで必要な情報が供給されている。しかし, 将 来にわたって NORAD 情報が公開される保証は無く, また, ロケット側よりピギーバック衛星に詳細な分離時の軌道情 報が提供されるケースは少なく，大学等では，独自に軌道 決定する能力を持つことが要求されている.

従来の軌道決定には, 大出力レーダーや, 高い精度のス ペクトラムアナライザが用いられており，これらを使えば 高い精度での決定が可能であるものの, それに必要なシス テムはきわめて高価である。そのため, 予算に限りのある 超小型衛星プロジェクトにおいては, 導入の負担が大きく、 その利用は難しいと考えられている。 ${ }^{1,2)}$

CubeSat のような超小型衛星プロジェクトの衛星通信機 材には, 市販のアマチュア無線機器を用いる場合が多く, これらの安価な機材を用いて簡易的に軌道決定を行う手段 が開発されれば，大学における超小型衛星開発領域の技術

\footnotetext{
*1 C2008 日本航空宇宙学会

平成 20 年 2 月 22 日原稿受理

*2 東京大学大学院新領域創成科学研究科先端エネルギー工学専攻

*3 東京大学大学院工学系研究科航空宇宙工学専攻

${ }^{* 4}$ Propulsion Design, EADS, Astrium, Stevenage, UK
}

力の向上につながると考えられ, またポスト NORAD 時代 においても運用に必要な基本的な軌道情報が得られるであ ろう。

\section{2. ドップラー変動による軌道要素の修正}

衛星の軌道要素は，ある時刻における人工衛星の位置を 予報するための情報である。地球近傍における人工衛星の 運動は, 地球重力の影響下で一般的に楕円軌道上を周回し ており，軌道を決定することにより一意に衛星の位置を予 報できる.

超小型衛星の追跡予報で使用される NASA Two Line Element(TLE)形式の軌道要素では, 軌道傾斜角・昇交点赤 経・近地点引数・離心率・平均運動・平均近点角・元紀が, 軌道の決定に必要な要素として提供されている.つまり, 軌道傾斜角・昇交点赤経により衛星の運動平面が決定され, 近地点引数・離心率・平均運動により運動平面上の楕円が 決定され, 平均近点角・元紀により軌道上における位相が 示される. その情報を元に, 軌道計算により, 衛星のある 時刻における 3 次元座標ならびに, 3 次元速度ベクトルが 決定される.

地上局を用いて衛星を観測する場合，地上局の 3 次元座 標值（緯度・経度・高度など）が与えられれば, ある時刻 における衛星の方位角・仰角および衛星より来る電波の周 波数のドップラーシフトが予測できる。逆に言えば, 地上 局から衛星を観測することで, 衛星の軌道要素を推定する ことが可能であることはいうまでもない.

市販のアマチュア無線機器で構成された超小型衛星用 の地上局を用いて上記の観測を行う場合, 機材による測定 精度の制約が問題となる. 地上局の位置決定については, 信頼性の高い地図が豊富に存在し, また容易に入手できる 
ことに加え，GPSによる測定も可能であり，十分な精度が えられる. しかしながら, 衛星からのダウンリンクが VHF やUHF のアマチュア無線帯である場合 (多くのケースそう である), 地上局のアンテナの指向性が悪く, 角度の分解能 が 30 度程度しか得られず，アンテナを用いて方位角・仰角 を決定することは困難である。一方で，ドップラー変化に よる周波数変動は, かなり高い精度で検出することができ る.これは，アマチュア無線機が，電波にのせられたアナ ログの音声信号を復調できるため，搬送波のわずかな周波 数変動を検出することが可能あるためである.

衛星の軌道を推定するにあたっては，もととなる不正確 な軌道要素からの補正, すなわち, ロケット分離時の軌道 や相乗りの大型の親衛星の軌道要素，あるいは古い軌道要 素からの補正を行って正しい衛星の軌道要素を推定するこ ととなる。この場合，衛星の軌道はもととなる軌道要素に 対して大きく変動する量の夕を補正すると目的を限ること によって，地上局から得ることができる限られた情報でも 軌道補正の目的を達成することが可能となる. 実際, 軌道 要素のうち, 衛星の運動平面と軌道形状に関する要素につ いては大きく変動しないが，軌道上の位相は空気抵抗によ る高度低下により時間とともに積分的に変化することにな るので,この位相情報を推定することが重要である.また， 実際の衛星運用においては，衛星の軌道予報は通信リンク を確保できる程度の精度が要求されるだけであるが，特に 位相情報に対するセンシティビティが大きい.

以上 2 点より, 衛星の軌道上の位相情報は低精度で簡易 的であっても推定する意義が非常に大きい，そこで，以下 では衛星からのドップラー情報を用いた位相情報の取得実 験を述べる。

\section{3. 観測実験のセッティング}

衛星信号のドップラー変化量の測定においては，840km 前後の高度で円軌道を周回している CubeSat XI-IV（2003 年打ち上げ）のビーコン信号をターゲットとして測定を行 った。もととなる軌道要素として，2007 年 9 月 11 日を元 紀とする TLE をTLE-B として，また，2008 年 1 月 3 日を 元紀とする TLE を TLE-A として，2008 年 1 月中に測定を 行った.

測定にあたっては，観測の回数を増やすため極軌道の受 信に有利な北極圈に位置する Luleå 工科大学 IRV（スウェ ーデン・Kiruna 市）の地上局設備にて測定を行った。衛星 信号は, 10 エレメントのクロス八木アンテナを衛星の予測 值に基づいて衛星方向に指向させている。また，受信には ICOM 社製アマチュア無線機の IC-910H を CW モードに設 定した。 CW モードにおいては $3 \mathrm{kHz}$ 幅のバンドパスフィ ルタが働いているため, VFO 周波数を衛星信号のドップラ 一変化について補正した予測值に基づいて追跡させた。ア ンテナ角度と周波数の追跡には, UNISEC 地上局ネットワ ークプロジェクトにて開発された Ground Station Management Service(GMS) を用いている。 ${ }^{3)}$ GMS では，軌
道予報に SGP4 アルゴリズムを用いており，1 秒おきに八 一ドウェアの制御を行っている。また, 運用は東京大学柏 キャンパス（千葉県柏市）から地上局ネットワークの枠組 みを利用して遠隔操作で行った。

CW モードで受信された信号は音声信号として受信機よ り取り出されるため，これをパソコンのサウンドカードを 通して $44.1 \mathrm{kHz}$ サンプリングの PCM データとして保存し た。保存された信号は，93ms（4096 点）ごとにパソコンで $\mathrm{FFT}$ 処理を行い，ピークの周波数の時間履歴に変換した. なお，XI-IV のビーコン信号は，モールス符号で変調され ている. XI-IV ビーコン信号の符号フレームの冒頭では周 波数の変化が発生するが, 本測定では, 周波数が安定した フレーム中盤以降のモールス信号の長点を中心とした時間 域において，ピークとなる周波数のデータをドップラーシ フトの解析に用いている.

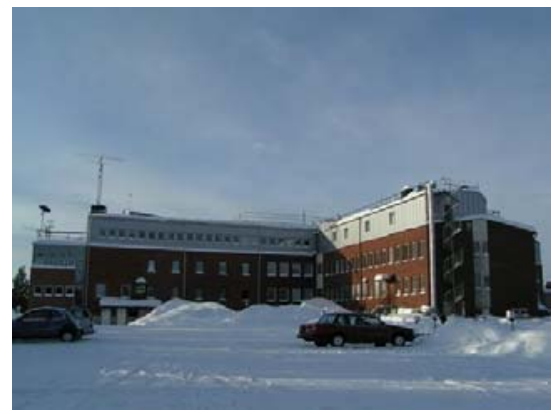

第 1 図 Luleå 工科大学 IRV 全景. 地上局アンテナは建物屋上左端 に設置.

\section{4. 観測および推定の結果}

4.1 軌道上の位相変化の検出と軌道要素の修正 第 2 困に 可視時間中に取得した音声信号の周波数変動の時間履歴の 一例を示す。第 3 図は時間方向の詳細である。

GMS による無線機制御が 1 秒単位であるため， 1 秒単位 の短周期的な変動が観測される (第 3 図).また，パス全体 にわたる長期的な周波数変動が確認される (第 2 図). 受信 機は軌道予報を元にフィードフォワード的に自動ドップラ ーシフト補正を行っているので，この変動は軌道予報の周 波数 $f_{1}$ と実際に受信された周波数 $f_{2}$ の差の変動を示してい る.この周波数の差の中には，PCの時刻設定，地上局の位 置情報等の誤差だけでなく，軌道予報に利用したTLE の誤 差の情報が含まれるので，それを逆に推定することができ る.

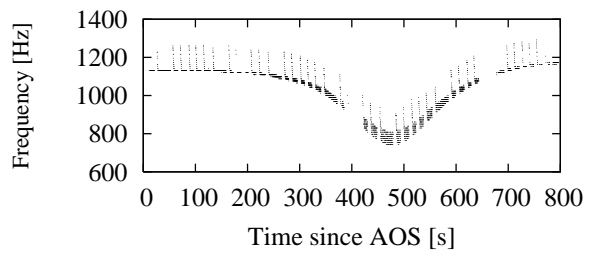

第 2 図 可視時間中のビーコン信号音声の周波数変動 


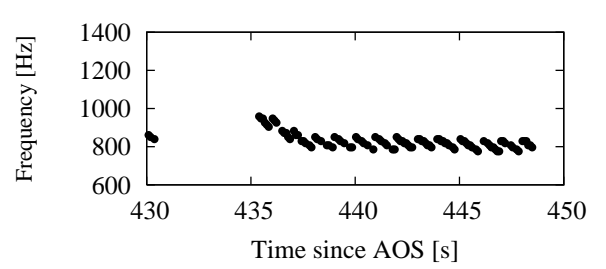

第 3 図 ビーコン信号音声の周波数の短期変動の様子

第 2 図のように，周波数の差が時間変動する要因は，第 4 図のように予想されるドップラーシフトと実際に発生す るドップラーシフトが時間的にずれているためで, 変動の ピーク（第 2 図では 480 秒近辺）は，予報される周波数 $f_{1}$ と実際の周波数 $f_{2}$ の差が最大になるところに表れる.

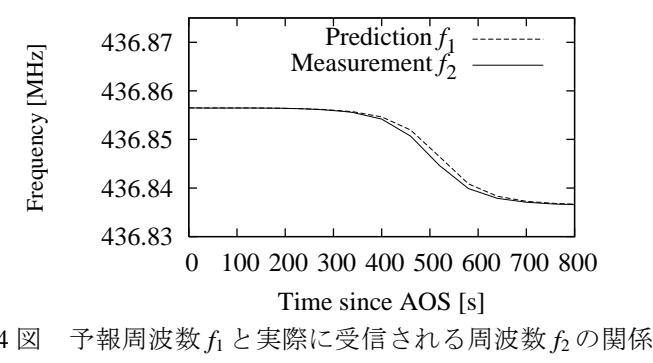

各可視時間内におけるこのピーク周波数変動について, その時刻における 1 秒単位の変動（第 3 図内の一断片の縦 の長さ）で規格化したものを第 5 図に示す. 第 5 図のグラ フの横軸は，信号を取得したパスにおいて最大仰角となっ た時刻である，午前 0 時(CET)を起点として示したもので ある。

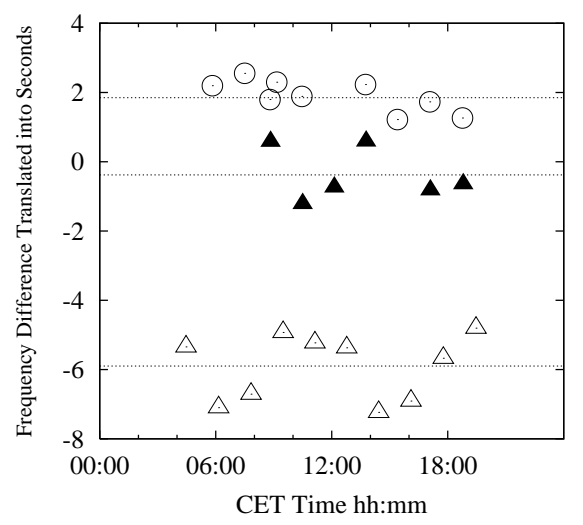

第 5 図 異なる TLE 情報に基づいた追跡によるドップラー周波数のず れの最大值の規格化量 $\bigcirc$ : TLE-A $\triangle$ : TLE-B $\Delta$ : TLE-C

1 秒単位の周期変動で変動する分量は, 軌道上での衛星 の 1 秒による位置の変化に由来するものである.したがっ て, 1 秒の変動量で周波数変動を規格化した值は, 軌道上 の予報值と実測值の差を秒単位で示したものと考えること ができ, ドップラー周波数の予報と実際のずれの最大值の 時間(秒)換算量(Frequency Difference Translated to Seconds, FDTS) と呼ぶ。なお, 衛星の送信機に起因する変動部分は 影響しないよう変動值としては評価していない。
パス中の最大の FDTS は同じTLE ではほぼ一定となるが, 異なる TLE との間では, 一定のオフセットが生じることが わかる.このような FDTS の差は, 衛星位置の位相方向へ のずれによるものであると予想される，たとえば，TLE-A は実際の衛星位置より約 2 秒（軌道上位置で約 $15 \mathrm{~km}$ ) 遅 れた位置に衛星があると考えていることを示しており，こ の情報から逆に「衛星はTLE-Aより2秒進んだ位置にいる」 と補正できるわけである. 変動量の多いTLE-B のケースで は TLE-B の元紀を 7 秒前進させる修正を行い, その補正 TLE（TLE-C）を使った場合の測定結果も第 5 図に示して いる.このような補正により, TLE 情報をより正確にでき, 運用にも効果をもたらすことが示された.

4.2 他の軌道要素のドップラー変化への影響 一般的にド ップラー周波数の変動は, 軌道上の位相のずれに帰結させ ることができるといえる. しかし, 軌道の幾何的な位置と 形状の違いによっても, FDTS は発生する. この場合, 正 しい軌道から予報軌道上に衛星位置を射影した見かけ上の 位相差として観測されることとなる．この場合，複数回の パスの間では, 投影関係が変化することにより, 異なった 位相差が観測される。一例として, 地上局の位置が正確で ない場合の影響を第 6 図に示す。ここでは, 地上局の位置 が正しい場合（66.85N，20.45E）と，あえて近隣の Kiruna 市中心部（66.7N, 20.3E）と間違った情報を与えた場合の予 報值との比較である。

地上局の位置が正確でない場合, 最大の FDTS が衛星の 通過時間帯によって大きく変化することがわかる．最大仰 角付近における衛星の通過方向一の地上局の位置のずれの 射影が大きい場合には, 衛星の見かけ上の位相差と認識さ れるため，大きなFDTS として出現すると考えられる．以 上の関係は，軌道傾斜角や昇交点赤経の情報の誤差にも同 様に言える.

このことより, 複数のパスを計測すること, また複数の 地上局でのドップラー変化を調べることにより, 軌道要素 の位相以外のパラメータの補正も可能であると考えられる. 現在, 数学的にその方法論を検討中である.

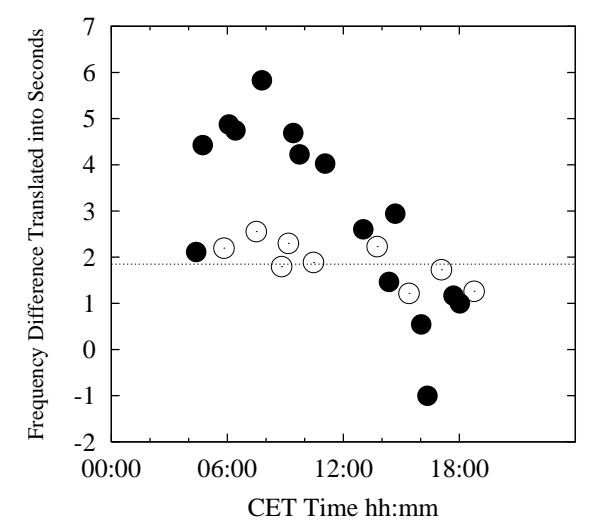

第 6 図 地上局位置の正確さによるドップラー変化量への影響. TLE-A を使用. $\bigcirc$ :正確な地上局位置 : Kiruna 市中心部 


\section{5. ま と め}

超小型衛星の運用に用いられる低コストのアマチュア無 線機器を用いて軌道要素の補正を行った。特に軌道上の衛 星の位相情報は重要であり，これはドップラーシフトによ り補正できることを示した．Luleå 工科大学 IRVの地上局 を利用した実験では, 最新の TLEに基づいた予報值でドッ プラー変化を追跡した場合，パス中の周波数変動量は 1,2 秒程度のずれだったが，3 カ月程前の軌道要素に基づいた 予報值は， 7 秒の周波数変動量が観測された。この結果に 基づいて，古いTLEの元紀を補正することにより，最新の TLE と同程度の周波数変動に抑えることができた. 以上よ り, 超小型衛星の運用で用いられる機材を用いて軌道推定 を行うことが可能であると考えられる.
本研究は，大学宇宙工学コンソーシアム(UNISEC)の支援 により遂行されました。この場を借りて, 感謝いたします.

\section{参 考 文 献}

1) Manheimer, W.M., Mesyats, G. and Petelin, M. I.: Applications of High Power Microwave Sources to Enhanced Radar Systems, in Applications of High-Power Microwaves, Gaponov-Grekhov, A. V. and Granatstein, V. L., Eds., Artech House, Norwood, MA, 1994, ch. 5, pp. 169-207.

2) 坂本祐二: テザー衛星システムの低コスト軌道決定手法に関する 研究, 九州大学 学位論文, 2005.

3) Nakamura, Y., Oda, Y. and Nakasuka, S.: Low-Cost and Reliable Ground Station Network to Improve Operation Efficiency for Micro/Nano-Satellites, 56th International Astronautical Congress, 2005. 